\title{
Analytical and Procedural Decision-Making Models for Process Improvement Projects in Testing Laboratories
}

\author{
S.S.S. Al-Busaidi, S.V. Ponomarev* \\ Department of Mechatronics and Process Measurement, Tambov State Technical University, \\ 106, Sovetskaya St., Tambov, 392000, Russia \\ * Corresponding author. Tel.: +7902 72860 32.E-mail: svponom@yahoo.com
}

\begin{abstract}
The article discusses an analytical model used in evaluation effectiveness and relative efficiency indicators of the processes performance in testing laboratories and a procedural model used to support manager in decision-making for implementing process improvement projects in the testing laboratories.
\end{abstract}

Keywords

Process; effectiveness; efficiency; decision-making; analytical model; procedural model.

(C) S.S.S. Al-Busaidi, S.V. Ponomarev, 2020

\section{Introduction}

The standard GOST ISO / IEC 17025-2019, which entered into force in the Russian Federation on September 1, 2019 and is identical to the international standard ISO / IEC 17025:2017 [1], first formulated the requirements for the need to take into account the risks and opportunities when carrying out activities in testing laboratories. When preparing a decision on the implementation of a project to improve the process in the management system [1-12] of the testing laboratory, for example, based on the risk assessment indicators [13, 17-19] or the improvement feasibility indicator, first proposed by the authors of this article in publications [17-19], most managers of testing laboratories (TL) usually have a need to assess the scope of change (preferably increment) in the values of the performance indicators and the relative effectiveness [20-23] of the test laboratory process after the implementation of the project to improve it. The analytical and procedural models are considered below in order to reduce the time spent in obtaining such estimates in the preparation of management decision-making using the methods described in publications [18, 19, 21, 24-27].

\section{Approaches to assessing the effectiveness and relative efficiency performance indicators of processes in testing laboratories at the stage of decision-making}

Our approach is based on the ideas of publications $[20,22,23,26]$ and is illustrated in Fig. 1.

Each process (Fig. 1a) has inputs $X_{\text {in }}$ and outputs $X_{\text {out }}$ Process inputs, for example, in a testing laboratory consist of different types of material products or services (test objects, information, reagents, and other resources, etc.). However, process outputs are material products or services (test results in a form of protocol, manufactured samples of materials with known properties, etc.) which appear as a result of the process.

\section{Analytical model for calculating the effectiveness and relative efficiency performance indicators of processes based on the results \\ of their implementation in both a reporting year and in the following year}

When assessing effectiveness performance indicators, we used such ratios as "actual time / planned time", "actual output/planned output", "planned costs / actual costs", [20, 22, 23] i.e. performance indicators of the process in the reporting year (Fig. 1b) can be represented as: 
a)
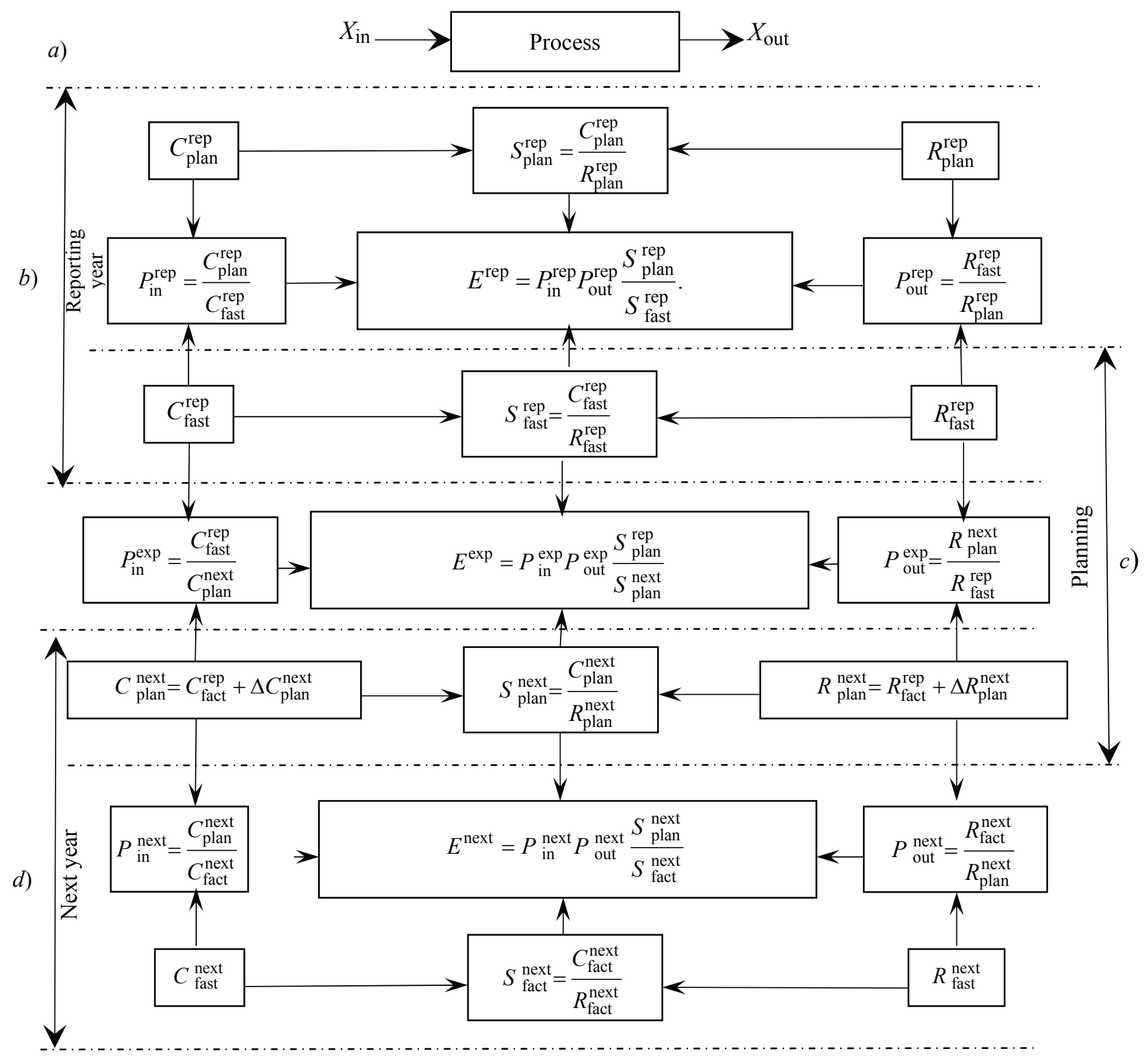

Fig. 1. A graphical model illustrating the analytical models for calculation of effectiveness in input and output of process and a relative efficiency indicator of the process:

$a$-schematic representation of process inputs and outputs $[20,26] ; b$-calculation model for effectiveness of the process at its input $P_{\text {in }}^{\text {rep }}$, output $P_{\text {out }}^{\text {rep }}$ and relative efficiency $E^{\text {rep }}$ in the reporting year $[20,26] ; c$ - calculation model for the expected

values of indicators; $P_{\text {in }}^{\exp }, P_{\text {out }}^{\text {exp }}$ and $E^{\text {exp }}$ of the process in the stage of planning activities for the following year; $d$ - calculation model for indicators $P_{\text {in }}^{\text {next }}, P_{\text {out }}^{\text {next }}$ and $E^{\text {next }}$ in the following year

$$
P_{\text {in }}^{\text {rep }}=\frac{C_{\text {plan }}^{\text {rep }}}{C_{\text {fast }}^{\text {rep }}} ; \quad P_{\text {out }}^{\text {rep }}=\frac{R_{\text {fast }}^{\text {rep }}}{R_{\text {plan }}^{\text {rep }}},
$$

where $P_{\text {in }}^{\text {rep }}, P_{\text {out }}^{\text {rep }}$ are the effectiveness of the process at input and output in the reporting year; $C_{\text {plan }}^{\text {rep }}, C_{\text {fast }}^{\text {rep }}$ are planned and actual costs of resources estimated at the input of the process in the reporting year; $R_{\text {plan }}^{\text {rep }}, R_{\text {fast }}^{\text {rep }}$ are planned and actual release of products (or services) evaluated at the output of the process.

To assess the efficiency of the process in the reporting year (see Fig. 1b), the following indicators should be used: 


$$
S_{\text {plan }}^{\text {rep }}=\frac{C_{\text {plan }}^{\text {rep }}}{R_{\text {plan }}^{\text {rep }}} ; \quad S_{\text {fast }}^{\text {rep }}=\frac{C_{\text {fast }}^{\text {rep }}}{R_{\text {fast }}^{\text {rep }}},
$$

where $S_{\text {plan }}^{\text {rep }}, S_{\text {fast }}^{\text {rep }}$ are planned and actual specific costs for a product or service in the reporting year.

On the basis of the performed studies to assess (measure) the efficiency of the management system process in the testing laboratory, we used the relative efficiency indicator (Fig. 1b) in the form:

$$
E^{\text {rep }}=P_{\text {in }}^{\text {rep }} P_{\text {out }}^{\text {rep }} \frac{S_{\text {plan }}^{\text {rep }}}{S_{\text {fast }}^{\text {rep }}} .
$$

Similar formulas should be used to calculate the effectiveness and efficiency performance indicators (see Fig. 1d) to assess the results of the process in the next year:

$$
\begin{gathered}
P_{\text {in }}^{\text {next }}=\frac{C_{\text {plan }}^{\text {next }}}{C_{\text {fast }}^{\text {next }}} ; \quad P_{\text {out }}^{\text {next }}=\frac{R_{\text {fast }}^{\text {next }}}{R_{\text {plan }}^{\text {next }}} ; \\
S_{\text {plan }}^{\text {next }}=\frac{C_{\text {plan }}^{\text {next }}}{R_{\text {plan }}^{\text {next }}} ; \quad S_{\text {fast }}^{\text {next }}=\frac{C_{\text {fast }}^{\text {next }}}{R_{\text {fast }}^{\text {next }}} ; \\
E^{\text {next }}=P_{\text {in }}^{\text {next }} P_{\text {out }}^{\text {next }} \frac{S_{\text {plan }}^{\text {next }}}{S_{\text {fast }}^{\text {next }}},
\end{gathered}
$$

where $P_{\text {in }}^{\text {next }}, P_{\text {out }}^{\text {next }}$ are effectiveness of the process at input and output in the next year; $S_{\text {plan }}^{\text {next }}, S_{\text {fast }}^{\text {next }}$ are planned and actual specific costs per unit of production/service in the next year; $E^{\text {next }}$ is a relative efficiency indicator of the process in the next year; $C_{\text {plan }}^{\text {next }}=C_{\text {fast }}^{\text {rep }}+\Delta C_{\text {plan }}^{\text {next }}$, are planned costs for the process in the next year, consisting of the actual costs $C_{\text {fast }}^{\text {rep }}$ in the previous year and the upcoming (planned) increase in costs $\Delta C_{\text {plan }}^{\text {next }}$ in the next year; $R_{\text {plan }}^{\text {next }}=R_{\text {fast }}^{\text {rep }}+\Delta R_{\text {plan }}^{\text {next }}$ are planned release of products/services at the output of the process in the next year, consisting of the actual output $R_{\text {fast }}^{\text {rep in the }}$ reporting (previous) year and the upcoming (planned) increase in release $\Delta R$ plan of products/services in the next year; $C_{\text {fast }}^{\text {next }}$ is actual costs for the process in the next year; $R$ fast is actual release of products/services in the next year.

\section{Analytical model used to calculate the effectiveness and the relative efficiency performance indicators of the processes at the stage of planning and preparation of decision-making}

A similar approach (to the above) illustrated in Fig. $1 c$ is proposed to be used at the planning stage (preparing a draft decision) when assessing the expected values of the effectiveness performance indicators at the input $P_{\text {in }}^{\exp }$ and output $P_{\text {out }}^{\text {exp }}$ of the process, as well as the expected values of the relative performance indicator $E^{\exp }$. In this case, the expected values of indicators are calculated by formulas:

$$
\begin{gathered}
P_{\text {in }}^{\text {exp }}=\frac{C_{\text {fast }}^{\text {rep }}}{C_{\text {plan }}^{\text {next }}} ; \quad P_{\text {out }}^{\text {exp }}=\frac{R_{\text {plan }}^{\text {next }}}{R_{\text {fast }}^{\text {rep }}} ; \\
S_{\text {fast }}^{\text {rep }}=\frac{C_{\text {fast }}^{\text {rep }}}{R_{\text {fast }}^{\text {rep }}} ; \quad S_{\text {plan }}^{\text {next }}=\frac{C_{\text {plan }}^{\text {next }}}{R_{\text {plan }}^{\text {next }}} ; \\
E^{\text {exp }}=P_{\text {in }}^{\exp } P_{\text {out }}^{\text {exp }} \frac{S_{\text {fast }}^{\text {rep }}}{S_{\text {plan }}^{\text {next }}} .
\end{gathered}
$$

It should be noted that when preparing decisions on the feasibility of implementing a project to improve business processes in a testing laboratory or management system process, first of all, the expected value of the relative efficiency indicator $E^{\exp }$ should be taken into account. If the expected value of the indicator $E^{\exp }$ is greater than or equal to 1 (at least slightly less than 1), the implementation of the proposed improvement project should be considered appropriate.

\section{A procedural model to support the manager's activity in preparing decisions about the process improvement feasibility in testing laboratory}

The developed procedural model to support the process of work of the manager (decision-maker) when working out a decision on the feasibility of the implementation of the project prepared by experts in order to improve the activities in the process under consideration is presented in Fig. 2.

After the decision-maker (DM) determines the testing laboratory process that requires improvement, the team of experts created by the (DM) in accordance with recommendations of problem-solving methodology $[5,22]$, determines the actual situation at 


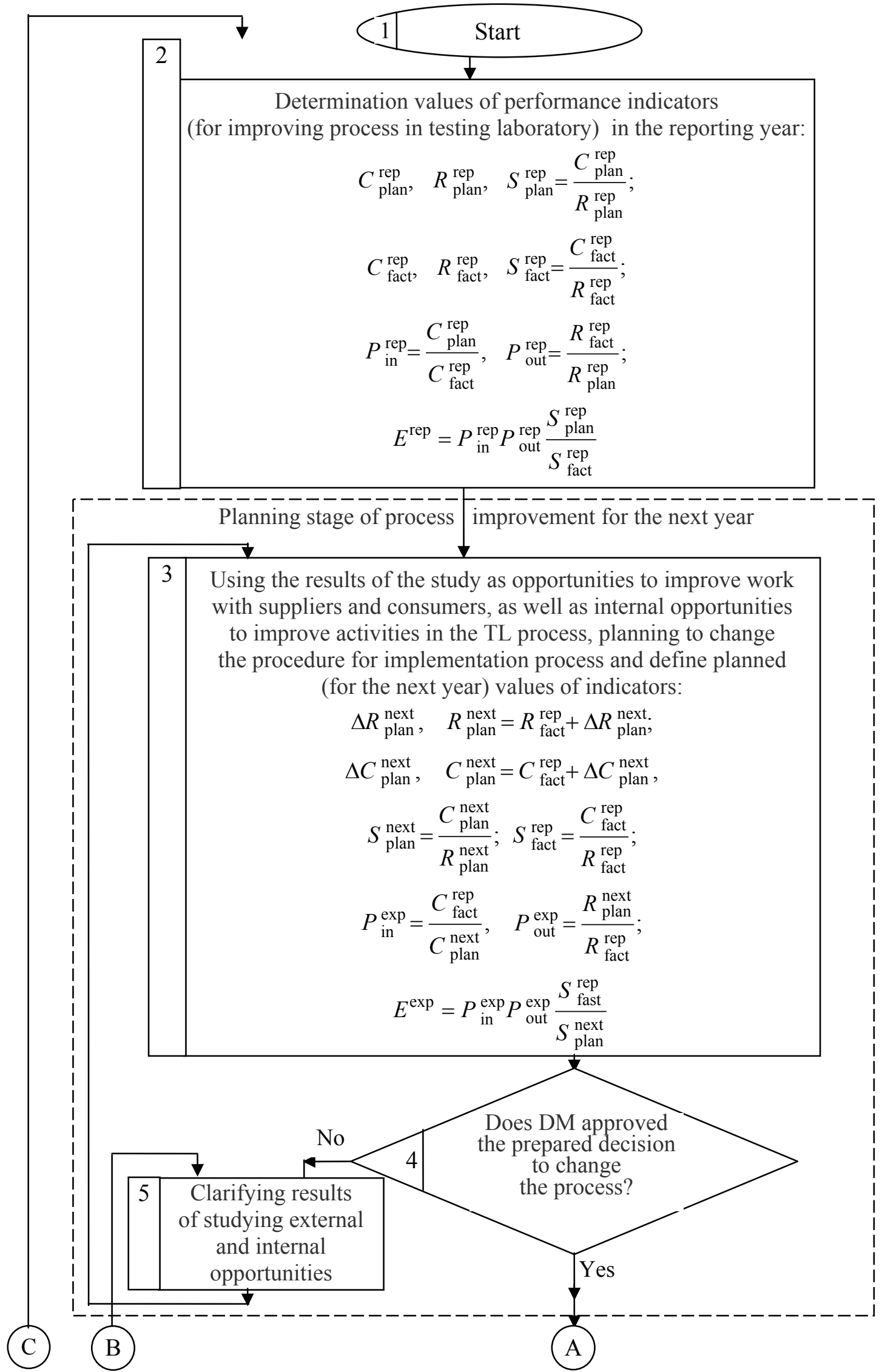

Fig. 2. Analytical and procedural models to support work of the DM in preparation of decision-making (see p. 71) 


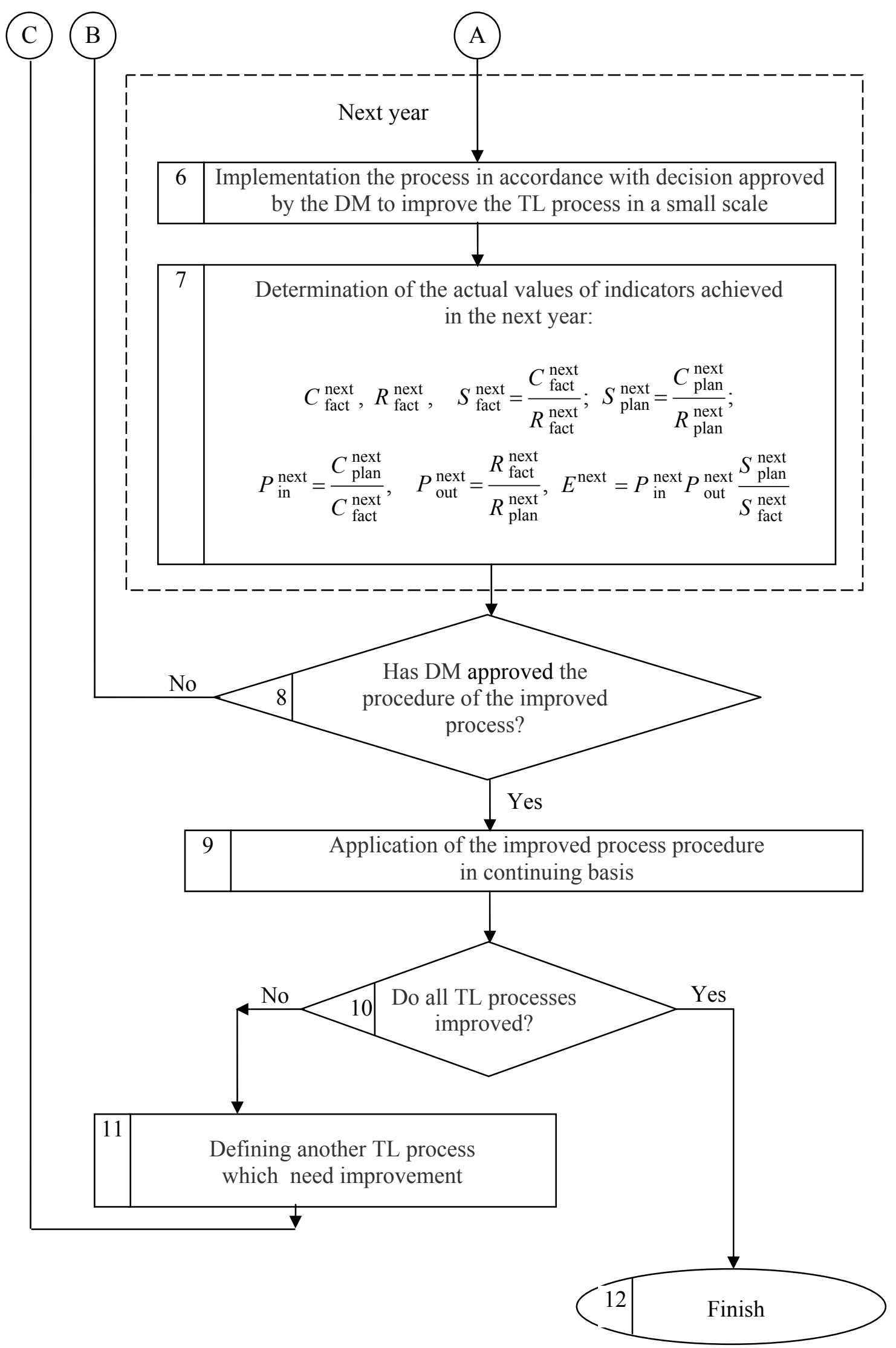

Fig. 2. Continued 
the beginning of work with the implementation of this process. It includes determination values about performance indicators of this process in the previous (reporting) year shown in Block 2 in Fig. 2, namely:

$$
\begin{aligned}
& C_{\text {plan }}^{\text {rep }}, \quad R_{\text {plan }}^{\text {rep }}, \quad S_{\text {plan }}^{\text {rep }}=\frac{C_{\text {plan }}^{\text {rep }}}{R_{\text {plan }}^{\text {rep }}} ; \\
& C_{\text {fact }}^{\text {rep }}, \quad R_{\text {fact }}^{\text {rep }}, \quad S_{\text {fact }}^{\text {rep }}=\frac{C_{\text {fact }}^{\text {rep }}}{R_{\text {fact }}^{\text {rep }}} \\
& P_{\text {in }}^{\text {rep }}=\frac{C_{\text {plan }}^{\text {rep }}}{C_{\text {fact }}^{\text {rep }}}, \quad P_{\text {out }}^{\text {rep }}=\frac{R_{\text {fact }}^{\text {rep }}}{R_{\text {plan }}^{\text {rep }}} ; \\
& E^{\text {rep }}=P_{\text {in }}^{\text {rep }} P_{\text {out }}^{\text {rep }} \frac{S_{\text {plan }}^{\text {rep }}}{S_{\text {fact }}^{\text {rep }}} .
\end{aligned}
$$

After clarifying the situation with the process in the reporting year, the team of experts takes the following steps:

- exploring opportunities to improve work with suppliers (in order to improve the quality of purchased materials and products used in testing, as well as to reduce the cost of these purchases);

- working with customers (consumers of testing laboratory services) in order to identify opportunities to increase their satisfaction with testing laboratory services, and increases the number of tests performed for them;

- studying the internal possibilities of improving the activities in the process of testing laboratory in terms of increasing customers satisfaction and reducing the cost of the process.

The team of experts develops a project to improve activities in the considered process of the testing laboratory. The team prepares and presents a version of the management decision to the decision-maker (DM). As a part of the prepared draft decision, the head (Director, Manager or DM) of the testing laboratory is provided with information about the expected values of the indicators presented in Block 3 (Fig. 2), namely:

$$
\begin{gathered}
\Delta R_{\text {plan }}^{\text {next }}, \quad R_{\text {plan }}^{\text {next }}=R_{\text {fact }}^{\text {rep }}+\Delta R_{\text {plan }}^{\text {next }} \\
\Delta C_{\text {plan }}^{\text {next }}, \quad C_{\text {plan }}^{\text {next }}=C_{\text {fact }}^{\text {rep }}+\Delta C_{\text {plan }}^{\text {next }}, \\
S_{\text {plan }}^{\text {next }}=\frac{C_{\text {plan }}^{\text {next }} ;}{R_{\text {plan }}^{\text {next }}} ; \quad S_{\text {fact }}^{\text {rep }}=\frac{C_{\text {fact }}^{\text {rep }}}{R_{\text {fact }}^{\text {rep }}} \\
P_{\text {in }}^{\text {exp }}=\frac{C_{\text {fact }}^{\text {rep }}}{C_{\text {plan }}^{\text {next }}}, \quad P_{\text {out }}^{\text {exp }}=\frac{R_{\text {plan }}^{\text {next }}}{R_{\text {fact }}^{\text {rep }}}
\end{gathered}
$$

$$
E^{\exp }=P_{\text {in }}^{\exp } P_{\text {out }}^{\exp } \frac{S_{\text {fast }}^{\text {rep }}}{S_{\text {plan }}^{\text {next }}} .
$$

If the calculated expected value $E^{\exp }$ of the relative efficiency indicator (the prepared project to improve activities in the process of the testing laboratory) exceeds, is equal to or slightly less than 1, then the DM (Director, Manager, Head of laboratory) usually makes a decision about the approval (Block 4) and subsequent implementation (initially on a small scale) of the project prepared by the experts' team. Otherwise, members of the experts' team proceed to clarify the results of studying external and internal opportunities to improve the activities in the process of TL (block 5) and then repeat the steps described in Blocks 3 and 4 in Fig. 2.

\section{Implementation of a small-scale project to improve the performance of the process under consideration of the testing laboratory (TL)}

After the DM has approved the prepared decision to change the test process under consideration, the necessary changes are made to the procedure of the process with the participation of the experts' team. These changes are made initially on a small scale. For example, if there are six installation types to be tested in the laboratory, first it is necessary to purchase renewable materials, raw materials and components for the modernization of only one installation.

After making all the necessary changes to the installation, the process in question on this installation (Block 6) is performed (on a small scale) in accordance with the DM's approved decision on implementing the project to improve the process.

After accumulating the necessary experience for practical use of the improved process (for example, during the following year), the team set the actual values of performed indicators to be achieved in the next year:

$$
\begin{gathered}
C_{\text {fact }}^{\text {next }}, R_{\text {fact }}^{\text {next }}, \quad S_{\text {fact }}^{\text {next }}=\frac{C_{\text {fact }}^{\text {next }}}{R_{\text {fact }}^{\text {next }}} ; S_{\text {plan }}^{\text {next }}=\frac{C_{\text {plan }}^{\text {next }}}{R_{\text {plan }}^{\text {next }}} ; \\
P_{\text {in }}^{\text {next }}=\frac{C_{\text {plan }}^{\text {next }}}{C_{\text {fact }}^{\text {next }}}, \quad P_{\text {out }}^{\text {next }}=\frac{R_{\text {fact }}^{\text {next }}}{R_{\text {plan }}^{\text {next }}}, \\
E^{\text {next }}=P_{\text {in }}^{\text {next }} P_{\text {out }}^{\text {next }} \frac{S_{\text {plan }}^{\text {next }}}{S_{\text {fact }}^{\text {next }}},
\end{gathered}
$$

which are presented in Block 7 in Fig. 2. 
If during the pilot implementation of the improvement project in the following year (initially on a small scale at one installation), a high value of the relative efficiency of $E^{\text {next }} \geq 1$ or $E^{\text {next }} \approx 1$ is obtained, the DM decides (Block 8 ) to approve a new procedure for the implementation of the improved process. Otherwise, they proceed to the implementation of the steps in Block 5 in Fig. 2, i.e. repeat the steps to study the external and internal opportunities to improve the procedure for the implementation of the test process under consideration, and then again proceed to the steps described in Blocks 3, 4, 6 and 7.

\section{Application of the improved process on an ongoing basis}

If the DM has decided (Block 8) to approve a new procedure for implementing the improved process, they proceed to the full-scale application of this procedure for performing the improved process on an ongoing basis (Block 9). At the same time, for the case of six installations considered in this article, the remaining five installations are modernized to carry out the test process under consideration and, subsequently, all tests on the existing six installations are carried out according to the approved improvement procedure for their implementation (approved by the DM).

After successful implementation of the project to improve the considered test process, another TL process that requires improvement (Blocks 10 and 11 in Fig. 2) is selected and the above steps described in Blocks (2-11) are repeated. The implementation of the procedural model to support DM' work (in preparing the decision to improve the test-processes in TL) is finished (Block 12) only after all the test processes performed in the laboratory are improved.

\section{The use of effectiveness and efficiency indicators} in TL processes to help a decision-maker to decide on the implementation of the project to improve the business process of input testing of incoming raw materials of "White Spirit" in the TL

We consider an example of a situation, in which the director of the testing laboratory has to make a decision about purchasing a device to improve the specific type of a business process - "White spirit" testing. There were additional costs required, and details of that are shown in Table 1.

The upcoming costs presented in Table 1 increased the planned costs in the next year by about 491thousand Russian Rubles, which corresponded (Table 2) to the expected planned costs $C_{\text {plan }}^{\text {next }}=2011.4$ Russian Rubles in the following year. However, the purchase of the device provided an opportunity to increase the number of orders for a specific type of tests for about $50 \%$ (from $R_{\text {fact }}^{\text {rep }}=146$ to $R_{\mathrm{plan}}^{\text {next }}=216$ ).

At the request from the director of the laboratory, calculations of the expected efficiency of test process under consideration after the acquisition of this device presented in Table 2 were performed.

Table 1

Information about planned and actual costs in 2017 to improve the incoming testing of raw material "White Spirit" in the testing laboratory

\begin{tabular}{clcc}
\hline No. & \multicolumn{1}{c}{ Expenses Type } & $\begin{array}{c}\text { Planned costs, } \\
\text { thousand Russian } \\
\text { Rubles }\end{array}$ & $\begin{array}{c}\text { Actual costs, thousand } \\
\text { Russian Rubles }\end{array}$ \\
\hline $1 \quad$ Cost of purchasing the device "Sulfur Analyzer ASE-1" & 423.0 & 423.0 \\
$2 \quad \begin{array}{l}\text { Cost of employee training contract in continuing education } \\
\text { courses in another city }\end{array}$ & 40.0 & - \\
$3 \quad \begin{array}{l}\text { Employee travel expenses for training courses in another } \\
\text { city }\end{array}$ & 20.0 & 8.6 \\
\hline & $\begin{array}{l}\text { Additional annual expenses (for calibration of the device, } \\
\text { transportation to the place of calibration, payment of } \\
\text { consumables, etc.) }\end{array}$ & 8.0 & 431.6 \\
\hline
\end{tabular}


Information about planned and actual (total) costs and calculation results for the indicators of effectiveness and efficiency of the incoming testing of raw material "White Spirit" in the testing laboratory (TL)

\begin{tabular}{|c|c|c|c|c|c|}
\hline \multirow{2}{*}{ Expenses and results in TL } & \multicolumn{2}{|c|}{ Reporting year 2016} & \multirow{2}{*}{ Planning } & \multicolumn{2}{|c|}{ Next year 2017} \\
\hline & Plan & Fact & & Plan & Fact \\
\hline $\begin{array}{l}\text { 1. Costs of the testing process, } \\
\text { thousand Russian Rubles }\end{array}$ & $C_{\mathrm{plan}}^{\text {rep }}=1704.4$ & $C_{\text {fact }}^{\mathrm{rep}}=1520.4$ & & $C_{\mathrm{plan}}^{\mathrm{next}}=2011.4$ & $C_{\text {fact }}^{\text {next }}=1943.1$ \\
\hline $\begin{array}{l}\text { 2. Number of tests carried out } \\
\text { within the process, PCs }\end{array}$ & $R_{\mathrm{plan}}^{\mathrm{rep}}=144$ & $R_{\text {fact }}^{\text {rep }}=146$ & - & $R_{\mathrm{plan}}^{\text {next }}=216$ & $R_{\text {fact }}^{\text {next }}=218$ \\
\hline $\begin{array}{l}\text { 3. Specific costs per unit, } \\
\text { thousand Russian Rubles/PCs }\end{array}$ & $S_{\text {plan }}^{\text {rep }}=11.836$ & $S_{\text {fact }}^{\mathrm{rep}}=10.414$ & & $S_{\mathrm{plan}}^{\text {next }}=9.314$ & $S_{\text {fact }}^{\text {next }}=8.913$ \\
\hline \multirow[t]{2}{*}{$\begin{array}{l}\text { 4. Effectiveness } \\
\text { of the process }\end{array}$} & & $P_{\mathrm{in}}^{\mathrm{rep}}=1.121$ & $P_{\text {in }}^{\exp }=0.756$ & & $P_{\text {in }}^{\text {next }}=1.035$ \\
\hline & - & $P_{\mathrm{out}}^{\mathrm{rep}}=1,014$ & $P_{\text {out }}^{\text {exp }}=1.479$ & - & $P_{\mathrm{out}}^{\text {next }}=1.009$ \\
\hline $\begin{array}{l}\text { 5. Relative efficiency } \\
\text { (dimensionless) }\end{array}$ & & $E^{\mathrm{rep}}=1.137$ & $E^{\exp }=1.118$ & & $E^{\text {next }}=1.045$ \\
\hline
\end{tabular}

When performing these calculations, the data presented in Table 1 were summarized with the already known values of the actual costs for the implementation of the business process in the previous year.

From the calculations performed at the planning stage according to the above methodology and presented in the fourth column of Table 2 followed that despite a noticeable decrease in the expected effectiveness of the process at the input $P_{\text {in }}^{\exp }=0.756$, the increase in the expected effectiveness at the output of the process $P_{\text {out }}^{\text {exp }}=1.479$ made the expected increase in the number of tests (orders) from 146 to 216. The expected relative efficiency (dimensionless) of the process was at the level $E^{\exp }=1.118$.

The expected value $E^{\exp }=1.118$ in Table 2 indicated the feasibility of the planned purchase of the device. Therefore, the director of the testing laboratory decided to implement the proposed project to improve the business-process by allocating funds for the purchase of the device "Sulfur Analyzer ASE-1".

In the right column of Table 2, the figures of actual values of the effectiveness and efficiency in the implementation of tests calculated by following the results of work in 2017 are italicized. The fact that the actual value of the relative (dimensionless) efficiency of the process $E^{\text {next }}=1.045$ was higher than 1 confirmed the correctness of the decision taken by the director of the testing laboratory to purchase the device to improve the business process.

\section{Conclusion}

The analytical and procedural models used for decision-making in project implementation to improve the process of the testing laboratory indicate the practical usefulness of the research results presented in the article. The above results can be used in preparing decisions on feasibility of improving the processes in the testing laboratory and management systems [1-12].

\section{References}

1. ISO/IEC 17025. General requirements for the competence of testing and calibration laboratories, 2017. Available: ISO Publications https://www.iso.org/ publication/PUB100424.html

2. Bieńkowska A. Wdrazanie systemu zarzaogonekdzania według normy ISO/IEC 17025 w laboratoriach badawczych i wzorcujaogonekcych - wyniki badań empirycznych [The implementation of the management system in accordance with ISO/IEC 17025 in testing and calibration laboratories - the results of empirical research]. Przeglad Elektrotechniczny. 2012, 88 (12B), 251-254.

3. Wadhwa V., Rai S., Thukral T., Chopra M. Laboratory quality management system: Road to accreditation and beyond. Indian J Med Microbiol. 2012, 30 (2), 131-140.

4. Westgard J.O., Westgard S.A. Quality control review: implementing a scientifically based quality control system. Annals of Clinical Biochemistry. 2016. 53(1), 32-50.

5. Al-Busaidi S.S.S., Sosedov G.A., Ponomarev S.V. Formirovanie, vnedrenie $\mathrm{i}$ practicheskoe primenenie 
processov sistemi menedzhmenta kachestva v ispitatel'noi' laboratorii, orientirovannoi' na proizvodstvennuyu, kommercheskuyu I obrazovatel'nuyu sferi deyutel'nosti: Monografiya [Formation, implementation and practical application of quality management system processes in the testing laboratory focused on production, commercial and educational spheres of activity: Monograph]. Tambov: Publishing house FGBOU VPO “TSTU”, 2012, 120 p. (Rus)

6. Kimothi S.K. The handbook of laboratory quality management and accreditation ISO/ IEC 17025 and ISO 15189: $1^{\text {st }}$ ed. Jaipur, India: Raj Publishing House; 2009, 19-20.

7. Nillson Orsini J. The essential Deming: leadership principles from the father of quality W. Edwards Deming, New York: McGraw-Hill, 2013.

8. Westgard J.O., Westgard S.A. Basic quality management systems, Madison WI: Westgard QC, Inc., 2014.

9. Berte L.M. Laboratory Quality Management: A Roadmap. Clin Lab Med. 2007, 27, 771-790.

10. Grochau I.H. Caten ten C.S. A Process Approach to ISO/IEC 17025 in the implementation of a quality management system in testing laboratories. Accreditation and Quality Assurance. 2012, 17(5), 519-527.

11. Boldyrev I.V. Karpov Yu.A., Paneva V.I. The accreditation system for Russian analytical laboratories and its development . Accred Qual Assur. 2007, 12, 405-408.

12. Squirrell A. Conformity assessment: providing confidence in testing and calibration. Accred Qual Assur. 2008, 13, 543-546.

13. Kachalov V.A. Riski i vozmozhnosti v stsndarte ISO 9001:2015: porozn' ili vmeste [Risks and opportunities in ISO 9001:2015: separately or together]. Metodi menedzhmenta kachestva. 2016, 7, 22-26 (Rus)

14. Bagimov I.A. Taranenko V.A. Primenenie apparata nechetkoi' logiki dlya ocenki prioritetnogo chisla riska $\mathrm{v}$ metodologii FMEA [Application of fuzzy logic to assess the priority number of risks in the FMEA methodology]. http://www.donntu.edu.ua/russian/konf/mashinebuild/arhiv/v ipusk32_2006.pdf

15. Ponomarev S.V. Prakticheskie podkhodi k octnke riskov $\mathrm{v}$ SMK. [Practical approaches to risk assessment in the QMS]. Metodi menedzhmenta kachestva, 2016, 7, 30-35 (Rus)

16. Solodkov E.I. Ponomarev S.V. et al. Primenenie FMEA-analiza dlya uluchsheniya processa graduirovki elektronnikh vesov [Application of FMEA analysis to improve the calibration process of electronic scales]. Metodi menedzhmenta kachestva. 2004, 8, 47-49 (Rus)

17. Ponomarev S.V. Al-Busaidi S.S.S. Primenenie ball'nikh kvalimetricheskikh shkal dlya ocenki indikatora "vozmozhnosti" uluchsheniya v SMK [The use of qualitative scoring scales for the evaluation of the indicator "possible" improvement in QMS]. Metodi menedzhmenta kachestva. 2016, 11, 14-18 (Rus)

18. Al-Busaidi S.S.S. Shakirova T.I., Ponomarev S.V. Primenenie pokazatelei' ispolneniya deyatel'njsti pri planirovanii i prinyatii upravlencheskogo resheniya ob uluchshenii vkhodnogo kontrolya sir'ya [Application of performance indicators in the planning and management decision to improve the input control of raw materials]. Trasactions of Tambov State Technical University. 2018, 2, 258-270. (Rus)

19. Al-Busaidi S.S.S., Ponomarev S.V. K voprosu o formalizatcii verbal'nykh ocenok, poluchennikh ekspertnimi metodami, pri podgotovke $\mathrm{k}$ prinyatiyu reshenii' $\mathrm{v}$ sisteme upravleniya ispytatel'noi' laboratoriei' [On the issue of the formalization of verbal evaluations obtained by expert methods, in preparation for making decisions in the control system of the testing laboratory]. Prikaspii'skii' zhurnal: upravlenie $i$ visokie tekhnologii. 2018, 3 (43), 59-69 (Rus)

20. Ponomarev S.V. Mironov S.V. Formirovanie i ocenka pokazatelei' rezul'tativnosti i effectivnosti processov SMK / S.V. Ponomarev, // Standarti i kachestvo [Formation and evaluation of effectiveness and efficiency indicators of QMS processes]. 2007, 8, 70-72 (Rus)

21. Ponomarev S.V. et al. Vvedenie $v$ upravlenie kachestvom processov, produkcii i uslug po trebovaniyam i rekomendaciyam mezhdunarodnikh standartov ISO serii 9000 v redakcii 2015 goda: uchebnoe posobie [Introduction to quality management of processes, products and services on the requirements and recommendations of international standards ISO 9000 as amended in 2015: Study Guide]. Saarbrucken: Lambert Academic Publishing, 2018, 291 p. (Rus)

22. Ponomarev S.V. et al. Upravlenie kachestvom processov i produkcii. V $3 \mathrm{kn}$. Kn. 2: Instrumenti i metodi menedzhmenta kachestva processov $\mathrm{v}$ proizvodstvennoi', kommercheskoi' i obrazovatel'noi' sferakh: uchebnoe posobie [Quality management of processes and products. In 3 volumes. Vol. 2: The tools and techniques for quality management of processes in production, commercial and educational spheres: Study Guide]. Tambov: Izd. FGBOU VPO “TGTU”, 2012, 212 p. (Rus)

23. Ponomarev S.V. et al. Upravlenie kachestvom produkcii. Instrumenti i metodi menedzhmenta kachestva: Uchebnoe posobie [Product quality management. Tools and methods of quality management: Study Guide]. Moscow: RIA "Standarti i kachestvo", 2005, 248 p. (Rus)

24. Kozlov V.N., Sistemnii' analiz, optimizaciya $i$ prinyatie reshenii': ucheb. posobie [System analysis, optimization and decision-making: Study Guide]. SPb.: Izdvo Politekhn. un-ta, 2011, 244 p. (Rus)

25. Sokolov N.N. Razrabotka upravlencheskikh reshenii'. Vvedenie $v$ kurs lekcii'. Uchebno-metodicheskoe posobiye [Development of management decisions. Introduction to the course of lectures. Study Guide]. Moscow: Izd-vo "Sputnik+", 2012, 37 p. (Rus)

26. Ponomarev S.V. Al-Busaidi S.S.S., Yemelyanov A.A. Upravlencheskie resheniya $v$ sisteme menedzhmenta ispytatel'noi' laboratorii [Management decisions in the management system of the testing laboratory] Kontrol' kachestva produktsii. 2015, 12, 21-25. (Rus)

27. Zadeh Lotfi. From computing with numbers to computing with words - from manipulation of measurements to manipulation of perceptions. International Journal of Applied Math and Computer Science. 2002, 12(3), 307-324. 